\title{
University Students' Awareness of the Use and Application of Solar Energy in Uganda
}

\author{
Ademola Olatide Olaniyan (PhD)*, Haman Biita \\ Kampala International University, Uganda \\ *Corresponding Author
}

\begin{abstract}
The concern for alternative source of power supply with the intention of maximizing the naturally and abundantly available solar energy is on the increasing measure in the developed and developing countries. Research and development studies suggest an optimistic future for the use and application of solar energy as a major source of renewable energy. To secure such a promising future in maximizing solar energy in a developing country like Uganda there is a need to investigate the level of awareness of the use and application amongst university students. The study employed survey technique using questionnaire to investigate the level of awareness of advantages and benefits there are on the use and application of solar energy. The study population is the university students selected purposively from Universities in Kampala, Uganda. Data collected from the study were analysed by comparing the mean standard deviation and Pearson moment correlation, and the research hypotheses were tested on 0.005 level of significance using regression analysis in order to determine the relationship between the level of awareness of the respondents and application of solar energy. Further suggestions made to elicit the spread of the usefulness and application of this alternative power supply in Uganda.
\end{abstract}

Key words: Solar energy, awareness, application, renewable energy

\section{INTRODUCTION AND LITERATURE REVIEWED}

$\mathrm{T}$ The demand for the use of energy in the $21^{\text {st }}$ century is on increasing measure on daily basis. This is evident in both local and global demands for energy use and in the rate at which energy is emphasized in developed, developing and under-developed world. From more powerful computers to larger televisions and the latest gadgets, the demand for additional energy supply is increasing each day. The role that energy plays in terms of resources, supply and utilisation in developed and developing countries manifest and it is evident in areas of oil exploration. Oil which has been a major source of energy supply for decades is now experiencing a major setback in the sense that the oil producing countries could no longer make available oil needed at affordable prices. So energy technology programmes that aimed at reducing dependence on imported oil sources, developing indigenous resources, promoting energy conservation and harnessing renewable sources flourished from that time. These programmes continue in importance and have been refined in each of the developed nations. The agencies that direct the programmes are now well established and publication and promotion of the knowledge gained is an important function. Within each nation are government agencies that have particular responsibility for energy, its policy, economics and technological development (Adeyoyin et al., 2019; Okonya \& Kroschel, 2013).

The sun is a renewable energy which exists abundantly in nature as solar energy, it contributes immensely to source of alternative power supply. The international energy agency stated that the sun exists as a nuclear reaction that releases energy called photons, which travels 93 million miles from the sun to the earth in about 8.5 minutes. These photons impact our planet to generate enough solar energy in about sixty minutes to theoretically satisfy global energy needs for an entire year. This energy is enhanced by different technologies to perform a variety of activities such as cooking food, water heating, among others (Van de Graaf, 2012).

Solar energy, radiant light and heat from the sun, is harnessed using a range of ever-evolving technologies such as solar heating, solar photovoltaics', solar thermal electricity, solar architecture and artificial photosynthesis (Florini, 2011). A great amount of energy can be harnessed from the sun. The amount of energy reaching the Earth Surface every day from the Sun is far greater than the energy that of man needs for the foreseeable future. The key to using this vast source of energy is developing effective methods for collecting and storing this energy. "Solar power is arguably the cleanest and the most reliable form of renewable energy available" (Key World Energy Statistics, 2013). Compared to other forms of energy such as firewood, charcoal and biogas is cleaner and it is widely available and abundant. In Uganda the sun's rays are almost directly overhead due to its location along the equator and has average temperature of 21 degrees to 23 degrees.

In Uganda, $85 \%$ of the population does not have access to electricity and that number is rising with the increase in population and urbanization. This is due early pregnancies, high school dropouts and low sensitization about use of solar energy other than drying food and clothes (Uganda Bureau of Statistics, 2016 - Google Scholar, n.d.). This is not given chance even at higher institutions of learning such as universities. This leads to production of graduates who cannot apply solar energy. Uganda is endowed with sunshine that, is well distributed and high throughout the year. The country experiences $5-6 \mathrm{KWh}$ per square meter radiation per day on flat surfaces. This insolation is highest at the equator but varies up to a maximum of $20 \%$ from place to place away from the equator (Komuhangi, 2018; Newman, 2013). It is 
highest in the dry areas (north-east) and the lowest in the mountainous area (southwest) of the country. This makes solar energy favourable in northeast where there is enough sunshine.

The government has long regarded solar energy as the only feasible option for renewable energy generation (Mugagga \& Chamdimba, 2019). This is because solar energy is cheap and easy to maintain once the initial costs are made not like the national grid electricity where one is required to pay for every unit used. According to the renewable policy of 2013, the country has a solar electricity potential of about $200 \mathrm{MW}$, 1650MW from biomass, 800MW from peat, 2200MW from hydropower stations and 400MW from geothermal energy. From this statistics, little electricity is produced from sun's radiations compared to other sources of electricity. This has led underutilization of energy resources like the sun. The recent survey by National Association of Professional Environmentalists (NAPE) revealed that there had been a number of considerable efforts put in place by the government to ensure that the solar energy is maximized in the country. This is evident in government's programs that support the use of solar energy called the Uganda Photovoltaic Pilots Project on Renewable Energy (UPPPRE). Different interventions and supports given to the various professional bodies and NonGovernmental Organizations (NGOs) to fast tract the availability of solar energy for industrial and domestic purpose in the urban and rural communities. One of the ways this was done was by supporting the initiatives of the NGQs and religious body (Church to be specific) to offer soft loans and credits for construction and installation solar technology accessories to the people or communities interested in using solar energy. (Mugagga \& Chamdimba, 2019; Turyareeba, 2001). With this intervention and considerable efforts there is low level of utilization of solar energy in the country.

\section{Statement of Problem}

Uganda is a country of about 44 million people with growth rate of $3.61 \%$ as at 2019 population statistics. The growing population is obviously exerting pressure on the existing natural resources in quest for food, habitation, social, economic and environmental wellbeing. This puts some energy sources like firewood, charcoal and biogas at stake, contributing in numerous ways to the depletion of Ozone layer while solar energy whose generation does not have adverse effect on the atmosphere and doesn't depend on environment but rather on the position of the place from the equator is left underutilized. Despite international bodies efforts on sensitization about protection of Ozone layer and the government intervention and efforts to cushion the effects of the population growth rate on the economy and the environment by encouraging the use of solar energy as alternative power supply in other to reduce adverse effect of other energy sources and the dependence of communities and individuals on the national grid electricity generated. All these efforts and interventions are not yielding considerable results as compared to the investment or efforts put in. This poor yield of result may not be unconnected to the knowledge of the level of awareness of solar energy in the society. The university students form a major component of the population of Uganda and they are the next generation and future of the country in terms of economy and political power. If the level of awareness is to change then the level of awareness amongst this next generation should be given a considerable attention. To this end this paper sought to find the level of awareness of the use and application of solar energy in Uganda.

\section{Objectives}

The main objectives for the study is to find out the university students' awareness of the use and application of solar energy in Uganda. Specifically, the study sought to examine;

1. The university students' awareness of solar energy in Uganda

2. The university students' application and use of solar energy in Uganda

3. The relationship between university students' awareness and application of solar energy in Uganda

4. The relationship between university students' perception and application of solar energy

Research Questions

1. What is the level of awareness and application of solar energy amongst university students in Uganda?

2. What is the relationship between the university students' awareness and application of solar energy in Uganda?

3. What relationship exist between students' perception and application of solar energy?

Research Hypothesis

$\mathrm{HO}_{1}$ : There is no significant relationship between the university students' awareness and application of solar energy in Uganda.

$\mathrm{HO}_{2}$ : There is no significant relationship between students' perception and application of solar energy in Uganda.

\section{METHODOLOGY}

The study employed a quantitative approach to investigate the university students' awareness and application of the use of solar energy in Uganda. The target population was all the university students in four Universities selected from Makindye District of Kampala City, Uganda. The study population were 1000 students randomly selected from these Universities, two hundred and fifty (250) questionnaires were randomly distributed to students in each university and a total of 700 were retrieved. Table 1.0 presents the demographic description of the respondent. 
Table 1.0: Demographic Description of the Study Sample

\begin{tabular}{|c|c|c|}
\hline QUANTITY & FREQUENCE & PERCENTAGE \\
\hline \multicolumn{3}{|c|}{ Gender } \\
\hline Male & 455 & 65 \\
\hline Female & 245 & 35 \\
\hline Total & 700 & 100 \\
\hline \multicolumn{3}{|c|}{ Age of Respondents } \\
\hline $20-29$ & 347 & 49.6 \\
\hline $30-39$ & 268 & 38.3 \\
\hline $40>$ & 85 & 12.1 \\
\hline Total & 700 & 100.0 \\
\hline \multicolumn{3}{|c|}{ Course of Study } \\
\hline Engineering & 381 & 54.4 \\
\hline Education & 198 & 28.3 \\
\hline Information Technology & 121 & 17.3 \\
\hline Total & 700 & 100.0 \\
\hline \multicolumn{3}{|c|}{ The University } \\
\hline A & 300 & 42.9 \\
\hline B & 203 & 29.0 \\
\hline $\mathrm{C}$ & 116 & 16.6 \\
\hline $\mathrm{D}$ & 81 & 11.6 \\
\hline Total & 700 & 100.0 \\
\hline
\end{tabular}

The research instrument was researcher designed questionnaire with face and content validity done by two science educators, one professional in renewable energy and one $\mathrm{PhD}$ student in renewable energy research. The questionnaire was designed on a five point Likert scale. Data collected were subjected to descriptive statistical analysis, the research questions were answered using spearman moment correlation and the research hypothesis was tested with multiple regression analysis.

\section{DATA ANALYSIS AND RESULTS}

Solar energy is gaining attention worldwide as the most promising alternative and reliable source of energy. With increasing population and development in Uganda, the need for alternative source of energy in form of solar energy cannot be overemphasized. Hence the need to investigate the level of awareness and application of solar energy, and relationship between the two amongst University students. This session presented the quantitative data analysis of the university students' awareness of the use and application of solar energy in Uganda. The session was further sub-divided as follows;

\section{Awareness of Solar Energy}

This session presented the level of knowledge or awareness of solar energy among university students by investigating their perception and cognition level. The items on the five point Likert Scale were presented in Table 2.0.
Table 2.0 shows the mean responses of University Students' awareness of solar energy. Five items were used in this construct and students were asked to rate them on a five Likert-scale by showing the level at which they agree of each of these statements. According to whether the use of solar energy could reduce environment degradation, this item was ranked first with $(\mathrm{Mean}=2.75, \mathrm{SD}=1.355)$, interpreted as Medium.

Table 2.0 Descriptive Statistics on Students' Awareness about Solar Energy

\begin{tabular}{|c|c|c|c|c|}
\hline Item & Mean & SD & Rank & Interpretation \\
\hline $\begin{array}{c}\text { Use of solar energy reduces } \\
\text { environment degradation }\end{array}$ & 2.75 & 1.355 & $\mathbf{1}$ & Medium \\
\hline $\begin{array}{c}\text { I can connect a solar panel } \\
\text { system for home consumption }\end{array}$ & 2.50 & 1.363 & $\mathbf{2}$ & Low \\
\hline $\begin{array}{c}\text { Solar energy is a good } \\
\text { substitute for electricity }\end{array}$ & 2.49 & 1.295 & $\mathbf{3}$ & Low \\
\hline $\begin{array}{c}\text { All students at our university } \\
\text { have knowledge of solar } \\
\text { energy }\end{array}$ & 2.43 & 1.260 & $\mathbf{4}$ & Low \\
\hline $\begin{array}{c}\text { I know the components used } \\
\text { to make solar panels }\end{array}$ & 2.10 & 1.091 & $\mathbf{5}$ & Low \\
\hline Average Mean & $\mathbf{2 . 4 5}$ & & & Low \\
\hline
\end{tabular}

Implying that on average students believe that the use of solar energy can conserve the environment. However, students showed low knowledge in the fact that they could not connect a solar panel system for home consumption this was ranked second in the construct with $($ Mean $=2.5, \mathrm{SD}=1.363$ ) interpreted as low. Regarding to Solar energy being a good substitute for hydroelectricity, this particular item was ranked third with (Mean=2.49, SD=1.295) interpreted as low.

\section{Application of Solar Energy}

In order to get a deeper understanding on the level of application of solar energy by University students, a five item construct aimed at ascertaining this was designed and the respondents were asked to rate these items on a five Likertscale to show the extent to which they agree or disagree with the statements and results were presented in form of Means and Standard deviations. The average Mean was used to give the general assessment of the entire variable.

Table 3.0: Descriptive Statistics on Students' Application of Solar energy

\begin{tabular}{|c|c|c|c|c|}
\hline Item & Mean & SD & Rank & Interpretation \\
\hline $\begin{array}{c}\text { Solar energy can be used for } \\
\text { cooking }\end{array}$ & 2.93 & 1.354 & 1 & Medium \\
\hline $\begin{array}{c}\text { My University has solar } \\
\text { panels as an alternative. }\end{array}$ & 2.79 & 1.409 & 2 & Medium \\
\hline I know some solar appliances & 2.69 & 1.358 & 3 & Medium \\
\hline I use solar energy at home & 2.62 & 1.389 & 4 & Medium \\
\hline $\begin{array}{c}\text { Solar panels do not run heavy } \\
\text { machines }\end{array}$ & 2.29 & 1.335 & 5 & Low \\
\hline Average Mean & $\mathbf{2 . 6 6}$ & & & Medium \\
\hline
\end{tabular}

Table 3.0 shows the mean responses of items under student' application of solar energy. The first item sought to know if students are in the knowledge that solar energy could be used for cooking. This item was ranked first with (mean $=2.93$, $\mathrm{SD}=1.354)$, this is interpreted as moderate. This implied that 
students averagely agree that solar energy could be used to prepare meal at home. With reference to whether their respective Universities had solar panels as an alternative to hydroelectricity, it was revealed that a moderate level of awareness occurs, ranking this item as second with (mean= $2.79, \mathrm{SD}=1.409)$, interpreted as moderate. This implied that student had little knowledge on the availability of solar panels in their Universities as most of them acknowledged that alternative means of power supply in their universities is generator. This finding is in agreement with Adeyoyin et al., 2019 who posited that university students' level of awareness of knowledge of solar energy is poor. The study also sought to find out if these students knew some solar appliances and this particular item was ranked third with (mean $=2.69, \mathrm{SD}=$ 1.358) interpreted as medium. This implied that students could not really relate the use of solar energy with major home appliances. This suggests that that apart from the basic minimum appliances like touches, solar lamps students could relate the use of solar energy to appliances such as powering television sets, solar cookers, solar oven etc. This is a sign that there is still an information gap to foster the applicability of solar energy. This particular finding is further more justified by the next item which sought to establish if students were using solar in their homes as this was ranked second last with (mean $=2.62, \mathrm{SD}=1.389)$ interpreted as medium. Contrary to the above finding students agreed that solar energy could run heavy machines. These findings are in consonant with Mohanasundari \& Devi, 2018 who studied on consumers' level of awareness of solar energy.

\section{Perception of Solar Energy}

Results in Table 4.0 reveal the mean response regarding the items under students' perception of solar energy. Nine items were used to measure the students' perception of solar energy and respondents were asked to rate them on a five Likertscale.

Table 4.0: Students' Perception of Solar Energy

\begin{tabular}{|c|c|c|c|c|}
\hline Item & Mean & SD & Rank & Interpretation \\
\hline $\begin{array}{c}\text { I prefer solar energy to } \\
\text { electricity. }\end{array}$ & 3.25 & 1.297 & 1 & Medium \\
\hline $\begin{array}{c}\text { Large number of solar } \\
\text { panels on the roof } \\
\text { weakens it }\end{array}$ & 3.09 & 1.302 & 2 & Medium \\
\hline $\begin{array}{c}\text { I can recognize and } \\
\text { differentiate between } \\
\text { solar and electricity }\end{array}$ & 2.97 & 1.413 & 3 & Medium \\
\hline $\begin{array}{c}\text { The solar power does not } \\
\text { perform heavy tasks }\end{array}$ & 2.93 & 1.445 & 4 & Medium \\
\hline $\begin{array}{c}\text { I have an experience in } \\
\text { the use of solar panels }\end{array}$ & 2.71 & 1.323 & 5 & Medium \\
\hline $\begin{array}{c}\text { The cost of maintaining } \\
\text { solar panel is high }\end{array}$ & 2.68 & 1.360 & 6 & Medium \\
\hline $\begin{array}{c}\text { Solar panels depreciate so } \\
\text { fast }\end{array}$ & 2.61 & 1.340 & 7 & Low \\
\hline $\begin{array}{c}\text { Solar panels are for only } \\
\text { rich people }\end{array}$ & 2.59 & 1.351 & 8 & Low \\
\hline $\begin{array}{c}\text { In my own opinion, solar } \\
\text { power is expensive to be } \\
\text { owned }\end{array}$ & 2.57 & 1.368 & 9 & Low \\
\hline Average Mean & 2.82 & & & Medium \\
\hline
\end{tabular}

In accordance to whether the respondents preferred solar energy to hydroelectricity, this item was ranked first with (mean $=3.25, \mathrm{SD}=1.297)$ interpreted as medium. This implied that students moderately agree that hydroelectricity is better for them compared to solar. This kind of finding can be justified by the fact that students had earlier on showed low levels of knowledge about solar energy and a medium level of applicability. The findings also revealed that large number of solar panels on the roof weakens it as this was ranked second with (Mean=3.09, $\mathrm{SD}=1.302$ ) interpreted as medium. Indicating that students moderately believe that placing multiple solar panels on the roof may lead to roof weakening. Regarding to whether or not students could recognize and differentiate between solar light energy and electricity, this particular item was ranked third in the construct with (Mean= 2.97, $\mathrm{SD}=1.413$ ) interpreted as medium and therefore moderate level. In line with solar power not being able to run heavy machines this was ranked fourth with $(\mathrm{Mean}=2.93$, $\mathrm{SD}=1.445$ ), interpreted as moderate. The study further sought to find out whether these students had some experience in the use of solar panels and this item was ranked fifth with (mean= 2.71, $\mathrm{SD}=1.323$ ) interpreted as medium. The study also revealed that most students on average believe that the cost of maintaining solar panel is high and that solar panels that are good are for the rich as these items where ranked six and eight in the construct.

Relationship Between Students' Awareness, Perception and Application of Solar Energy

Hypotheses $\mathrm{H} 01$ and $\mathrm{H} 02$ were tested to determine the relationship between students' awareness and application of solar energy, students' perception and application of solar energy.

Table 5.0: Correlation Coefficient between Application and Awareness of solar energy

\begin{tabular}{|c|c|c|c|c|}
\hline \multicolumn{5}{|c|}{ Correlations } \\
\hline \multirow{4}{*}{$\begin{array}{c}\text { Applicati } \\
\text { on }\end{array}$} & $\begin{array}{c}\text { Applic } \\
\text { ation }\end{array}$ & $\begin{array}{c}\text { Awarene } \\
\text { ss }\end{array}$ & $\begin{array}{c}\text { Percepti } \\
\text { on }\end{array}$ \\
\cline { 2 - 5 } & Correlation & 1 & $.257^{* *}$ & .000 \\
\cline { 2 - 5 } & Sig. (2-tailed) & & .000 & .996 \\
\hline \multirow{4}{*}{$\begin{array}{c}\text { Awarene } \\
\text { ss }\end{array}$} & $\mathrm{N}$ & 700 & 700 & 700 \\
\cline { 2 - 5 } & $\begin{array}{c}\text { Pearson } \\
\text { Correlation }\end{array}$ & $.257^{* *}$ & 1 & -.033 \\
\cline { 2 - 5 } & Sig. (2-tailed) & .000 & & .382 \\
\hline \multirow{3}{*}{$\begin{array}{c}\text { Percepti } \\
\text { on }\end{array}$} & N & 700 & 700 & 700 \\
\cline { 2 - 5 } & $\begin{array}{c}\text { Pearson } \\
\text { Correlation }\end{array}$ & .000 & -.033 & 1 \\
\cline { 2 - 5 } & Sig. (2-tailed) & .996 & .382 & 700 \\
\hline \multicolumn{2}{|c|}{$\mathrm{N}$} & 700 & 700 & \\
\hline \multicolumn{4}{|c|}{$* *$ Correlation is significant at the 0.01 level (2-tailed). } \\
\hline
\end{tabular}

The Pearson correlation coefficient value for application of solar energy and students' awareness about solar energy was $r$ $=0.257$ and the $\mathrm{p}$-value $=0.000$. This implies that there is a positive relationship between application of solar energy and students' knowledge. Therefore, the p-value (0.000) suggests 
the existence of a statistically significant relationship between application of solar energy and students' awareness. Similarly, perception and cognition had a positive and statistically significant relationship with application of solar energy with $\mathrm{r}$ $=0.996$ and a $\mathrm{p}$ - value 0.000 . Therefore, $\mathrm{H}_{\mathrm{O}} \& \mathrm{H}_{1}$ were rejected.

From the findings, it was observed that the correlation is not causational, therefore the need to run a multiple regression analysis in order to asses and quantify the influence that the independent variables have over the dependent variables. Hence a multiple regression analysis of students' awareness of the use and application of solar energy was further conducted. Table 6.0 presents the findings.

Table 6.0: Multiple Regression Analysis of Awareness and Application of Solar Energy

\begin{tabular}{|c|c|c|c|c|c|c|}
\hline \multicolumn{7}{|c|}{ Coefficients $^{\mathrm{a}}$} \\
\hline & \multirow{2}{*}{ Model } & \multicolumn{2}{|c|}{$\begin{array}{l}\text { Unstandardized } \\
\text { Coefficients }\end{array}$} & \multirow{2}{*}{$\begin{array}{c}\begin{array}{c}\text { Standard } \\
\text { ized } \\
\text { Coefficie } \\
\text { nts }\end{array} \\
\text { Beta }\end{array}$} & \multirow{2}{*}{$\mathrm{T}$} & \multirow{2}{*}{ Sig. } \\
\hline & & B & $\begin{array}{l}\text { Std. } \\
\text { Error }\end{array}$ & & & \\
\hline \multirow{3}{*}{1} & Application & 1.807 & .174 & & 10.375 & .000 \\
\hline & Awareness & .329 & .047 & .257 & 7.026 & .000 \\
\hline & Perception & .010 & .043 & .009 & .238 & .812 \\
\hline \multicolumn{7}{|c|}{ a. Dependent Variable: Application } \\
\hline
\end{tabular}

From the table, students' application of solar energy has a value of 1.807 when all the explanatory variable is zero. This means that even without the influence of explanatory variables, $18.07 \%$ level of solar application is realized. Similarly, 0.329 implies that for a unit increase in awareness amongst students, solar energy application increases by $32.9 \%$, keeping perception at zero. Lastly, 0.010 implies that for a unit increase in Perception, solar energy application increases by $1 \%$, keeping knowledge at zero.

\section{DISCUSSION ON FINDINGS}

Findings from the five items construct revealed that students' knowledge of awareness of the use of solar energy is low. This is evident in average mean value and standard deviation (Mean=2.49, $\mathrm{SD}=1.295$ ) as shown in Table 2.0. This is in line with the study of Adeyoyin et al., 2019 who find out that Nigerian students awareness of solar energy as alternative power source is low. Also, the findings showed that Uganda universities students' knowledge of application of solar energy and their perception of solar energy in relationship to its application is moderate (average mean value of 2.66 and 2.83 respectively). This is in consonant with the findings of Mohanasundari \& Devi, 2018 and Newman, 2013 who in their findings at different locations revealed low level of awareness of application of solar energy products.

From the hypotheses tested, it was observed that a strong positive relationship of $(\mathrm{r}=0.996)$ and statistically significant (p-value $<0.05$ ) existed between students' awareness of the use of and application of solar energy, and students' perception and application of solar energy. Therefore, hypotheses $\mathrm{H}_{01}$ and $\mathrm{H}_{02}$ were rejected, indicating that creating awareness about the use of solar energy positively influences students' perception and the application of solar energy in Uganda. This findings in agreement with the findings of Mugagga and Chamdimba (2019) and Furukawa (2014) who confirmed that awareness of solar energy help students' perception and application of solar energy and invariably resulted in better study habit and performance.

\section{CONCLUSION}

The level of awareness of the use of solar energy amongst university students in Uganda affects their knowledge of application and perception of solar energy. Generally, students showed low level of awareness of solar energy, there is need to create more awareness and to sensitize the students more on the application and use of solar energy in Uganda. Further studies can be conducted to refute or reaffirm this conclusion using University students from other region within Uganda.

\section{REFERENCES}

[1] Adeyoyin, S. O., Alawiye, M. K., \& Ewulo, O. R. (2019). Awareness and use of solar energy as alternative power source for ICT facilities in Nigerian university libraries and information centres. Library Philosophy and Practice, 2019. https://www.researchgate.net

[2] Florini, A. (2011). The international energy agency in global energy governance. Global Policy, 2(SUPPL.1), 40-50. https://doi.org/10.1111/j.1758-5899.2011.00120.x

[3] Furukawa, C. (2014). Do Solar Lamps Help Children Study? Contrary Evidence from a Pilot Study in Uganda. Journal of Development $\quad$ Studies, $\quad 50(2), \quad 319-341$. https://doi.org/10.1080/00220388.2013.833320

[4] Key World Energy Statistics. (2013). http://www.iea.org/publications/freepublications/publication/KeyWor ld2013.pdf

[5] Komuhangi, N. (2018). Supervisor-supervisee interaction and staff performance in Uganda: A cade study of ministry of energy and mineral development. http://umispace.umi.ac.ug/handle/20.500.12305/492

[6] Mohanasundari, R., \& Devi, N. (2018). Consumer Awareness of Solar Energy Products A Study with Special Reference to Tirupur District Abstract. International Journal of Engineering and Management Research Page Number, 8(1), 139-145. https://www.google.com

[7] Mugagga, R. G., \& Chamdimba, H. B. N. (2019). A Comprehensive Review on Status of Solar PV Growth in Uganda. Journal of Energy Research and Reviews, 3(4), 1-14. https://doi.org/10.9734/jenrr/2019/v3i430113

[8] Newman, H. R. (2013). The mineral industry of Uganda. In 2011 Minerals Yearbook: Vol. III (p. 206). International Monetary Fund. http://prd-wret.s3.amazonaws.com

[9] Okonya, J. S., \& Kroschel, J. (2013). Indigenous knowledge of seasonal weather forecasting: A case study in six regions of Uganda. Agricultural Sciences, 64(12), 641-648. https://doi.org/10.4236/as.2013.412086

[10] Turyareeba, P. J. (2001). Renewable energy: Its contribution to improved standards of living and modernisation of agriculture in Uganda. Renewable Energy, 24(3-4), 453-457. https://doi.org/10.1016/S0960-1481(01)00028-3

[11] Uganda Bureau of Statistics, 2016 - Google Scholar. (n.d.). Retrieved September 11, 2021, from https://scholar.google.co.za

[12] Van de Graaf, T. (2012). Obsolete or resurgent? The International Energy Agency in a changing global landscape. Energy Policy, 48, 233-241. https://doi.org/10.1016/j.enpol.2012.05.012 